\title{
Analysis of Technical, Economic and Allocative Efficiencies of CassavaProduction in Taraba State, Nigeria:
}

\author{
Aboki, E., A.A.U.jongur, J.I. Onuand I.I. Umaru \\ *Department of Agricultural Economic and Extension, TarabaState University, P.M.B. 1167 Jalingo, Nigeria \\ **Department of Agricultural Economic and Extension,ModibboAdama University of Technology Yola, \\ Adamawa State, Nigeria. \\ *** National Land Development Authority, Jalingo
}

\begin{abstract}
This work examined the production efficiency of cassava farms in Taraba State. A purposive sampling method was used to select 300 cassava farmers in the study area. Important information on inputs used and outputs realized in cassava production were collected from cassava farmers using structured questionnaire. The datacollectedwere analyzed using descriptive statistics, stochastic frontier production function and cost function. The estimated gamma parameter of stochastic frontier production function showed that about $92 \%$ variation in output among cassava farmers in the study area was due to differences in technical efficiency. The estimated elasticities of production with respect to farm size, family labour, hired labour and fertilizer were statistically significant at $1 \%$ and $5 \%$ level of significance respectively. The mean technical, allocative and economic efficiency were $0.887,0.856$ and 0.825 respectively, meaning that the sample farmers were relatively very efficient in allocating their limited resources with technical efficiency appears to be more significant than allocative and economic efficiency. The result of the study showed that the major factor affecting cassava productions in the study area were farm size, family labour, hired labour, fertilizer, house hold size, years of schooling and source of funds. These factors were significant and have positive influence on cassava output. It is thus recommended that farmers should be encouraged to adopt more intensive cultural practices instead of continued expansion in land put to cassava production.
\end{abstract}

Key words: Technical, allocative, economic efficiencies stochastic frontier production function and cost functions.

\section{Introduction}

Agriculture belongs to real sector of Nigeria economy. The activity of agriculture is characterized by: a multitude of small scale farmers that scattered over wide expanse of land area, with small holding ranging from 0.05 to 3.0 hectares per farm land, low capitalization and low yield per hectare (Ogundari and Ojo, 2007). Agriculture plays significant roles in the Nigerian economy despite the strategic importance of the oil sector. Agriculturalsector provides primary means of employment for many Nigerian and accounts for more than onethird of total Gross Domestic product (GTP) and labour force (FAO, 2003; World Bank, 2006, Ogundari and Ojo, 2007).The decline in the contribution of Agriculture to the country's GDP overtime is due to the slower growth of the sector relative to other sectors of the economy and most especially commercial exploration of petroleum (Ogundari and Ojo, 2007).

The national strategic importance of food is evident in its consideration as a key variable in matter relating to National Security and in planning against disaster and other emergencies. However, a major indicator of depressed performance of the Nigeria Agricultural sector is the food crisis experienced in the country in the pass years. Nigeria as a country endowed with a large expanse of land with tremendous potential resources and favourable climate for producing food and other raw materials for export and domestic industries has not been self-sufficient in food production (Ogundari and Ojo, 2007)

Cassava is an important root crop in Nigeria. It was introduced into Central Africa from South America. It is most widely cultivated crop in southern part of the country in terms of area devoted to it and number of farmers growing it (Ogunniyi,et al.,2012).

Cassava is important not only for food crop but as a major source of income for both urban and rural household. Nigeria is currently the largest producer of cassava in the world with annual production of about 37 million tons of tuberous roots (CBN, 2011). Both rich and poor farmers oftensell a high proportion of their cassava products than other crops (Ogunniyi et al, 2012). Cassava has some inherent characteristics which makes it attractive especially to smallholder farmers in Nigeria. Firstly, it is rich in carbohydrates, which makes it useful in some industries. It is available all year round compare to other crops as it is more tolerant to low soil fertility and resistant to drought, pests and diseases.

The food problem has been heightened by the relatively low level of productivity of resources used by the farmer in the country (Ojo, 2004). And to examine the productivity of the resources used by the 
cassavafarmer in the study area, this paper is therefore designed to:(i) identify the socio-economic characteristics of cassava farmers (ii) estimate current level of technical, allocative and economic efficiencies (iii) examine the factors affecting cassava production in the study area.

\section{Stochastic frontier production and cost function:}

\section{Theoretical Framework}

The stochastic frontier modeling is becoming increasingly popular because of its flexibility and ability to closely marry economic concepts with modeling reality. And, based on this, the model is employed in this paper to provide the basis for measuring farm-level technicaland allocative efficiencies which are the basis of estimating the economic efficiency of small scale cassava production in the study area.

The modeling, estimation and application of stochastic frontier production function to economic analysis assumed prominence in econometrics and applied economic analysis following farrell's (1957) seminar paper where he introduced a methodology to measure technical, allocative and economic efficiency of a firm. According to Farrell, technical efficiency (TE) is associated with the ability of a firm to produce on the isoquant frontier while allocative efficiency $(\mathrm{AE})$ refer to the ability of a firm to produce at a given level of output using the cost-minimizing input rations. Thus defining economic efficiency (EE)as the capacity of a firm to produce a predetermined quantity of output at a minimum cost for a given level of technology (Bravo et., 1997).

However, over the years, farrell's methodology had been applied widely, while undergoing many refinement and improvements. And of such improvement is the development of stochastic frontier model which enable one to, measure firm level technical and economic efficiency using maximum likelihood estimate (a corrected form of ordinary least square-(COLS)). Aigner et al. (1977) and meeusen and Van den Broeck (1977) were first to proposed stochastic frontier production function and since then many modification had been made to stochastic frontier analysis. Aigner et al. (1977) applied the stochastic frontier production function in the analysis of the U.S agricultural data. Battese and Corra (1977) applied the technique to the pastoral zone of eastern Australia. In Meeusen and Van den Broeck (1977) application, the technique was applied to the analysis of Ten French manufacturing industries. And more recently, empirical analysis has been reported by Battese et al. (1993), and Ojo (2004). The model used in this paper is based on the one proposed by Battese and Coelliet (1995) and Battese et al. (1996) in which the stochastic frontier specification incorporates models for the technical inefficiencies effects and simultaneously estimate all the parameters involved in the production and cost function models.

\section{Model specification:}

The stochastic frontier production function model of Cobb-Douglas functional form is employed to estimate the firm level technical and allocative efficiencies of the farmer in the study areas. The Cobb-Douglas functional form was used because: the functional form has been widely used in farm efficiency for the developing and developed countries, the functional form meets the requirement of being self-dual, allowing an examination of economic efficiency and lastly Kopp and Smith (1980) suggested that the functional form has a limited effect on empirical efficiency measurement.

The Cobb-Douglas production functional form which specifies the production technology of the farmers is express as follows: $Y_{i}=f\left(X_{i} ; \beta\right) \exp V_{i}-U_{i} \ldots \ldots \ldots \ldots \ldots \ldots \ldots \ldots \ldots \ldots \ldots i$

Where $Y_{i}$ represent the value of output, which is measure in naira $(\mathbb{N})$; $\mathrm{X}_{\mathrm{i}}$ represent the

Quality of input used in the production. The Vs are assumed to be independent and identically distributed random errors, having normal $\mathrm{N}\left(0, \sigma_{\mathrm{y}}^{2}\right)$ distribution and independent of the $\mathrm{U}_{\mathrm{i}} \mathrm{s}$. The $\mathrm{U}_{\mathrm{i}} \mathrm{s}$ are technical inefficiency effects which are assumed to be non-negative truncation of the half-normal distribution $\mathrm{N}\left(\mu, \sigma_{\mathrm{i}}^{2}\right)$.

The technical efficiency of individual farmers is defined in terms of the ratio of observed output to the corresponding frontiers output, conditional on the level of input used by the farmers. Hence the technical efficiency of the farmers is expressed as $\mathrm{TE}_{\mathrm{i}}=\mathrm{Y}_{\mathrm{i}} / \mathrm{Y}_{\mathrm{i}} *=\mathrm{f}\left(\mathrm{X}_{\mathrm{i}} ; \beta\right) \exp \left(\mathrm{V}_{\mathrm{i}}-\mathrm{U}_{\mathrm{i}}\right) / \mathrm{f}\left(\mathrm{X}_{\mathrm{i}} ; \beta\right) \exp \mathrm{Vi}=\exp (-$

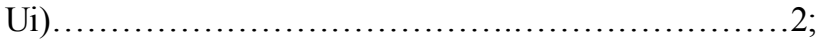

Where: $Y_{1}$ is the observed output and $Y_{1} *$ is the frontiers output. The TE ranges between 0 and 1 that is $0 \mathrm{~d}$ " Ted" 1.

The corresponding cost frontier of Cobb-Douglas functional form which is the basis of estimating the allocative efficiencies of the farmers is specified as follows:

$\mathrm{C}_{1}=\mathrm{g}\left(\mathrm{P}_{\mathrm{i}}, \mathrm{a}\right) \exp \left(\mathrm{V}_{\mathrm{i}}+\mathrm{U}_{\mathrm{i}}\right)$; =.... 3 ;

Where $\mathrm{C}_{1}$ represent the total input cost of the $\mathrm{i}$-th farmers; $\mathrm{g}$ is a suitable function such as the Cobb-Douglas function; $\mathrm{P}$ represent input prices employed by the $\mathrm{i}$-th farm in cassava production and measure in naira; $\mathrm{a}$ is the parameter to be estimated, $\mathrm{V}_{\mathrm{i}} \mathrm{s}$ and $\mathrm{U}_{\mathrm{i}} \mathrm{s}$ are random errors and assumed to be independent and identically distributed truncations (at zero) of the $\mathrm{N}\left(\mu, \sigma^{2}\right)$ distribution. Ui provides information on level of the allocative efficiency of the i-th farm. The allocative efficiency of individual farmers is defined in terms of the ratio of the predicted minimum cost $\left(\mathrm{Ci}^{*}\right)$ to observed cost $(\mathrm{Ci})$. That is $\mathrm{AE}=\mathrm{Ci} * / \mathrm{Ci}=\exp (\mathrm{Ui}) \ldots \ldots \ldots \ldots \ldots \ldots \ldots$; 
Hence, allocative efficiency ranges between zero and one.

\section{Study Area and Data Collection}

\section{Methodology}

This study was conducted in Taraba State. The State is located in the North Eastern part of Nigeria. The state lies between latitudes $6^{\circ} 30^{\prime}$ and $9^{\circ} 36^{\prime} \mathrm{N}$ of the equator and longitudes $9^{\circ} 10^{\prime}$ and $11^{\circ} 50^{\prime} \mathrm{E}$ of the Greenwich Meridian (TADP, 2004). The predominant economic activities of the people include crop and livestock production.

A purposive sampling procedure was employed to select the area of study. In the course of the study nine Local Government Areas (Ardo Kola, Bali, Donga, Gassol, Kurmi, Lau, Takum, Ussa and Wukari) were purposively chosen because of their preeminence in cassava production. Three villages were purposively selected in each of the nine Local Government Areas given total of 27 villages. A total of 300 farmers were then randomly selected from the 27 villages. Data were collected on inputs, costs of inputs, output and associated prices and income generated during the 2010/2011 production season using structured questionnaire. Data were also collected on other relevant variables such as sex, age, qualifications etc. for the purpose of this analysis.

\section{Analytical Techniques}

A number of analytical tools were used in this study. These included:

(a) The descriptive statistics such as Table, frequency and percentage was used to describe the socio-economic characteristics of cassava farmers

(b) The stochastic frontier production model was used to examine the input-output relationship,

The implicit form of the stochastic frontier production model is specified as follows;

$\operatorname{In} Y_{i j}=\beta_{o}+\beta 1 \operatorname{In} X 1+\beta_{2} \operatorname{In} X_{2}+\beta_{3} \operatorname{In} X_{3}+\beta_{4} \operatorname{In} X_{4}+\beta_{5} \operatorname{In} X_{5}+\beta_{6} \operatorname{In} X_{6}+\beta_{7} \operatorname{In} X_{7}+\left(v_{i}-u_{i}\right) \ldots \ldots \ldots . .5$;

where $Y_{\mathrm{i}}=$ cassava output $(\mathrm{kg} / \mathrm{ha})$

$\mathrm{X}_{1}=$ total land area under cultivation (ha)

$\mathrm{X}_{2}=$ family labour used (man days/ha)

$\mathrm{X}_{3}=$ hired labour used (man days/ha)

$\mathrm{X}_{4}=$ quantity of inorganic fertilizer used $(\mathrm{kg} / \mathrm{ha})$

$\mathrm{X}_{5}=$ expenses on land preparation $(\mathrm{N} / \mathrm{ha})$

$\mathrm{X}_{6}=$ quantity of cuttings used $(\mathrm{kg} / \mathrm{ha})$

$\mathrm{X}_{7}=$ quantity of agro- chemical used (liters/ha)

In $=$ logarithm to base e

$\mathrm{ij}=\mathrm{j}^{\text {th }}$ observation of the $\mathrm{i}^{\text {th }}$ farmer

$\mathrm{V}_{\mathrm{i}}-\mathrm{U}_{\mathrm{i}}=$ error term $(\varepsilon)$

$\beta_{\mathrm{o}}=$ constant term to be estimated

$\beta_{1}$ to $\beta_{7}=$ coefficients of the independent variables to be estimated

(c) The corresponding cost frontier of Cobb- Douglass functional form was used as the basis of estimating the allocative efficiencies of the cassava farmers in the study area. The implicit form of the cost frontier production form is specified as follows;

$\operatorname{InC}=\alpha_{0}+\alpha \operatorname{In} \mathrm{P}_{1}+\alpha \operatorname{In} \mathrm{P}_{2}+\alpha \operatorname{InP} \mathrm{P}_{3}+\alpha \operatorname{In} \mathrm{P}_{4}+\alpha \operatorname{In} \mathrm{P}_{5}+\alpha \operatorname{InP} \mathrm{P}_{6}+\mathrm{V}_{\mathrm{i}}+\mathrm{U}$ 6

Where $\mathrm{C}=$ total cost of production (in $\#$ )

$\mathrm{P}_{1}=$ cost of fertilizer (in $\mathrm{N}$ )

$\mathrm{P}_{2}=$ cost of labour (in $\#$ )

$\mathrm{P}_{3}=$ cost of cassava setts (in $)$

$\mathrm{P}_{4}=$ cost of chemicals (in $)$

$\mathrm{P}_{5}=$ cost of farm implements use (in $\mathrm{N}$ )

$P_{6}=$ other operating expenses (cost of transport, sacks and packaging) (in $N$ ).

The technical and allocative inefficiency model $\mu_{\mathrm{ij}}$ is defined by:

$\mu_{\mathrm{ij}}=\delta_{\mathrm{o}}+\delta_{1} \mathrm{Z}_{1}+\delta_{2} \mathrm{Z}_{2}+\delta_{3} \mathrm{Z}_{3}+\delta_{4} \mathrm{Z}_{4}+\delta_{5} \mathrm{Z}_{5}+\delta_{6} \mathrm{Z}_{6}$ .7

$\mu_{\mathrm{ij}}=$ denotes the technical inefficiency of the $\mathrm{i}^{\text {th }}$ farmer

$\mathrm{Z}_{1}=$ denotes number of extension contact

$Z_{2}=$ represent house hold size

$Z_{3}=$ represent years of formal education

$\mathrm{Z}_{4}=$ denotes years of farming experience of the $\mathrm{i}^{\text {th }}$ farmer

$Z_{5}=$ represent member of association; where one denotes member of association and zero otherwise

$Z_{6}=$ represent source of fund for farming; where one is for those who depend on personal saving for farming activities and zero otherwise

$\delta_{0}=$ constant term

$\delta_{1}$ to $\delta_{1}=$ unknown parameter to be estimated. 


\section{Results And Discusion}

\section{Socio-economic characteristics}

These were discussed under gender, age, marital status, educational level, years of farming experience and farm size (Table 1).

The socio-economic characteristic of cassava farmers' indicatedthat $61.3 \%$ of the respondents are male while $38.7 \%$ were female. This means that male population was more involved in cassava production than female. This finding is in consonance with the finding by Ogunniyi et al. (2012) who reported thatmale $(77.5 \%)$ dominate cassava production than the female $(22.5 \%)$ in Oyo State. The age distribution of the respondents indicated that majority (41.3\%) of the cassava farmers was between $38-49 \%$ years of age. The mean age was 42 years. This implies thatmost of the cassava farmers are in their active group and have the capacity to produce efficiently. The result also showed that married couples $(50 \%)$ constitute the bulk of cassava farmers. .Majority (46.7\%) of the cassava farmers cultivated on small farm size ranging between $0.25-1.00$ ha. The findings also showed that majority $(83.3 \%)$ of the sampled farmers were literate, as only $16.7 \%$ of them have never gone to school.The mean farming experience of the cassava farmers in the study area was 9 years. This implies that most of the cassava farmers have been in cassava production for a long time.

\section{Technical Efficiency}

The mean, maximum and minimum technical efficiencies obtained from the study were $0.887,0.984$ and 0.084 respectively. This showed that farmer with the best practice in the study area is 0.984 while farmer with the least practice is 0.084 .The frequencies of occurrences of the computed technical efficiencies in deciles ranges indicated that majority $(50 \%)$ of the farmers have technical efficiencies between $0.09-0.99$. The result shows that about $20 \%$ of cassava growers had technical efficiency below $70 \%$ while about $80 \%$ had technical efficiency from $70 \%$ and above. The study further revealed ample opportunity that exists for improving the level of technical efficiency of cassava production in the study area. Finding by Onu and Edon (2009) revealed that education, training knowledge and awareness improve technical efficiency of farmers. Therefore, to raise the level of technical efficiency of cassava farmers in the study area there is need to improve, the farmers' knowledge, skill and awareness in production. The finding revealed that farmers are efficient in deriving maximum output from input, given the available resources. This information is presented in figure 1.

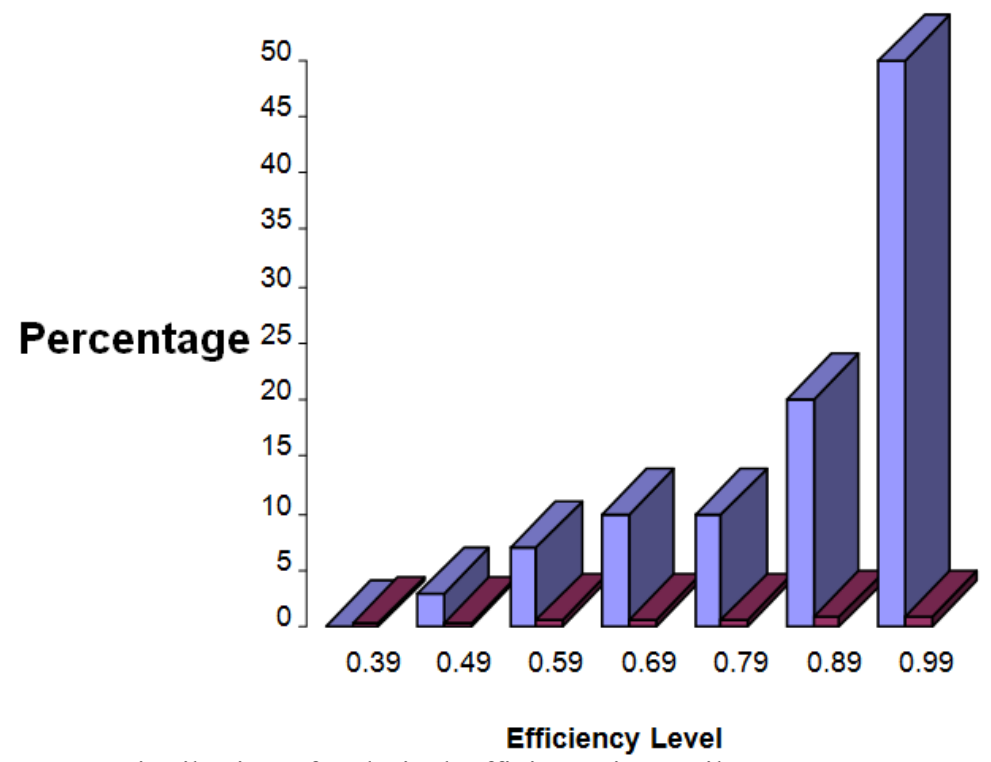

Fig 1: Frequency Distribution of technical Efficiency in Decile Ranges.

\section{Allocative Efficiency}

The mean, maximum and minimum allocative efficiencies obtained from the study were $0.856,0.978$ and 0.476 respectively. The result showed that there is ample opportunity for improvement on the level of allocative efficiency in cassava production in the study area, as $25 \%$ of cassava farmers had allocative efficiency below $70 \%$ while about $75 \%$ had allocative efficiency of $70 \%$ and above. Onu and Edon, (2009) reported that training/orientation to the farmers, especially towards the new technology and other farming practices improve allocative efficiency of farmers. The result revealed that farmers in the study area are fairly efficient in producing cassava at a given level of output using the cost minimizing input ratio. Policy that will 
improve farmers' efficiency should be developed by both government and the private sectors in order to boost cassava production in the study area and the nation at large. The allocative efficiency is presented in figure 2.

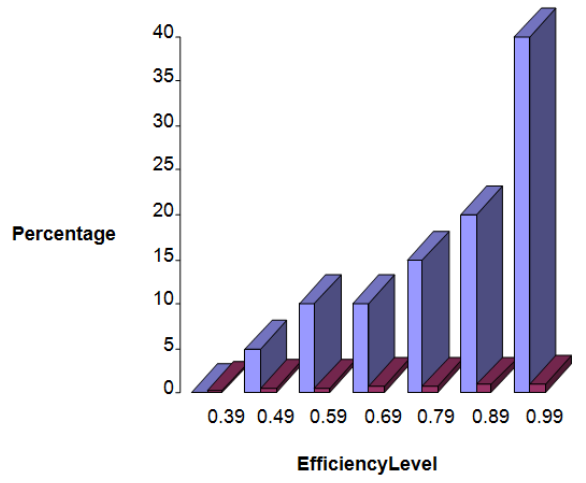

Fig 2: Frequency Distribution of Allocative Efficiency in Decile Ranges

\section{Economic Efficiency}

The result revealed that the minimum, maximum and mean economic efficiency of the farmers in the study area was $0.458,0.923$ and 0.825 respectively. The results showed that economic efficiency of cassava farmers ranged from $0.458-0.923$ this indicated that a wide gap exist between the efficiency of best economically efficient farmers and that of the least economically efficient farmer. The mean economic efficiency is 0.825 , meaning that cassava farmers in the study area were fairly economically efficient in the use of scarce resources. The estimate also reveals that for an average cassava farmer in the study area to attain the level of the most economically efficient farmers in the sample, the farmers must experience efficiency gain of $17.5 \%$ (ie 1.00-8.25). The result also reveals that the least economically efficient farmer will require efficiency gain of about $54.2 \%$ (i.e $1.00-0.458$ ) to be able to attain the level of the most economically efficient farmers in the sample.The computed economic efficiencies (E.E) which is an inverse of cost efficiencies, differs substantially among the cassava farmers in the study area. The frequency of occurrence of the computed economic efficiency in decile range indicates that majority (39\%) of the farmers have economic efficiencies between $0.80-0.89$. The result also shows that about $21 \%$ of the farmers had efficiency below $70 \%$ while $79 \%$ of the farmers had EE of $70 \%$ and above which is an indication that farmers in the study area are fairly economic efficient. This implies that farmers are efficient in producing a given quantity of cassava at a minimum cost for a given level of technology. The economic efficiency is presented in figure 3 .

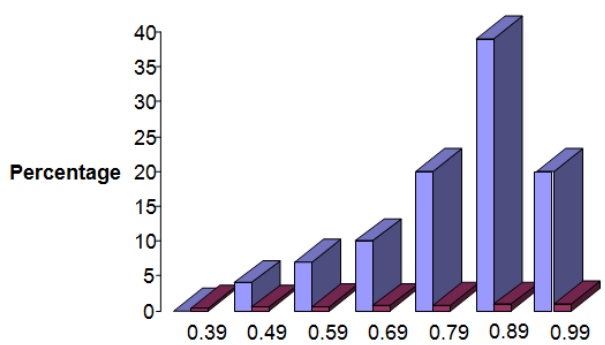

Fig 3: Frequency Distribution of Economic Efficiency Decile Ranges

\section{Factors Affecting Cassava Production In The Study Area.}

The factors affecting cassava production in the study area is presented in Table 2: The result showed that family labour, farm size, hired labour and quantity of fertilizer were statistically significant at $5 \%$ and $1 \%$ level of significance respectively. This means that a $5 \%$ increase in manday of family labour would lead to an increase in the output of cassava by $5.68 \%$. The implication of this is that famers with relatively large house hold size have the potential to increase their total farm output in that labour is needed for the execution of important operations such as weeding and peeling. The result suggests that family labour is a significant factor that is associated with changes in cassava output and this is in consonance with findings by Ogundari and Ojo (2007).

The elasticity of production with respect to land is statistically significant at $1 \%$ significance level. This means that a $1 \%$ increase in the hectare of land used in the production of cassava will lead to an increase in the output by $5.24 \%$.

The elasticity of production with respect to fertilizer is statistically significant at $1 \%$ level of significance. The study also revealed that fertilizer is one of the major inputs which improve productivity. A $1 \%$ 
increase in the used of fertilizer would lead to an increase in cassava output by $5.22 \%$. The result agrees with the findings by Ogundari and Ojo (2006) who reported that inorganic fertilize increase cassava output.

The elasticity of production with respect to hired labour is statistically significant at $1 \%$ level of significance. This implies that a $1 \%$ increase in hired labour would cause an increase in cassava output by $3.32 \%$.

The inefficiency result is presented in Table 2. The elasticity of production with respect to years of schooling is negative and statistically significant at $1 \%$ level of significance, meaning that farmers with formal education tend to be more efficient in cassava production; this is due to their enhanced ability to acquire technical knowledge, which makes them move closer to the frontier output. It is very possible that farmers with education respond easily to the use of improved technology, such as the application of fertilizers, use of pesticides, herbicides and so on thus assisting the farmers to produce close to the frontier. This finding is in conformity with the finding of Tanko and Jirgi (2008) and Ortega et al., (2005) who reported a positive relationship between education and technical efficiency. This shows that education is an important factor that reduces inefficiency among cassava farmers in the study area. The coefficient of household size is negative and statistically significant at 5\% level. This implies that household size is an important factor that contributes positively to technical efficiency in the study area.

The estimated elasticity of production with respect to source of fund is negative and statistically significant at $5 \%$ level of significance. This implies that farmers who largely depend on their personal saving for farming were inefficient compared to the farmers who in addition to their personal saving obtain credit facilities for their farming activities. This finding is in consonance with the work of Eno, (2004) who reported a significant relationship between source of fund and technical efficiency of the farmers.

Table1: Socio-economic characteristics of cassava farmers

\begin{tabular}{lll}
\hline Characteristics & Frequency & Percentage \\
\hline Gender & 184 & 61.33 \\
Male & 116 & 38.67 \\
Female & & \\
Age & 25 & 8.33 \\
$14-25$ & 78 & 26 \\
$26-37$ & 124 & 41.33 \\
$38-49$ & 50 & 16.67 \\
$50-61$ & 23 & 7.67 \\
$>61$ & & \\
Marital Status & 150 & 50 \\
Married & 90 & 30 \\
Single & 60 & 20 \\
Others & & \\
Educational Level & 90 & 30 \\
Primary & 120 & 40 \\
Secondary & 40 & 13.33 \\
Tertiary & 50 & 16.67 \\
Informal & & \\
Years of Farming Experience & 90 & 30 \\
$1-5$ & 120 & 40 \\
$6-10$ & 60 & 20 \\
$11-15$ & 20 & 6.67 \\
$16-20$ & 10 & 3.33 \\
$>20$ & & \\
Farm Size & 140 & 46.67 \\
$0.25-1.00$ & 75 & 25.00 \\
$1.25-2.00$ & 60 & 20.00 \\
$2.25-3.00$ & 15 & 5.00 \\
$3.25-4.00$ & 10 & 3.33 \\
$>4.00$ & & \\
\hline - & & \\
\hline & & \\
\hline
\end{tabular}

Source: Field data 2010

Table2: Maximum likelihood estimates of the Stochastic Frontier production function

\begin{tabular}{llllc}
\hline Variables & parameter's & coefficient & Standard error & t - ratio \\
\hline Constants & $\beta_{0}$ & 8.763 & 0.0216 & $9.768^{* * *}$ \\
Farm size & $\beta_{1}$ & 0.524 & 0.0468 & $8.690^{* * *}$ \\
Family labour & $\beta_{2}$ & 0.568 & 0.0561 & $1.682^{* *}$ \\
Hired labour & $\beta_{3}$ & 0.332 & 0.0551 & $7.651^{* * *}$ \\
Quantity of fertilizer & $\beta_{4}$ & 0.522 & 0.1048 & $5.142^{* * *}$ \\
Expon land preparation & $\beta_{5}$ & -0.514 & 0.0718 & $0.647 \mathrm{Ns}$ \\
Cassava setts & $\beta_{6}$ & 0.279 & 0.0601 & $0.669 \mathrm{Ns}$ \\
Agro-chemical & $\beta_{7}$ & -0.767 & 0.1313 & $0.784 \mathrm{Ns}$ \\
Inefficiency model & & & &
\end{tabular}




Constants
Extension contact
House hold size
Years of schooling
Farming experience
Member of association
Source of fund
Sigma square
Gamma
Log likelihood

\begin{tabular}{llll}
$\delta_{0}$ & -8.034 & 0.034 & $16.426^{* * *}$ \\
$\delta_{1}$ & 0.463 & 0.0234 & $3.081^{* *}$ \\
$\delta_{2}$ & -0.214 & -0.0303 & $2.464^{* *}$ \\
$\delta_{3}$ & -0.365 & -0.0220 & $8.247^{* * *}$ \\
$\delta_{4}$ & 0.178 & 0.1809 & $3.938^{* *}$ \\
$\delta_{5}$ & 0.084 & 0.4977 & $2.142^{* *}$ \\
$\delta_{6}$ & -0.689 & -0.2913 & $-3.645^{* *}$ \\
$\delta^{2}$ & 1.246 & 0.0024 & $9.806^{* * *}$ \\
$\Gamma$ & 0.915 & 0.00020 & $14.760^{* * *}$ \\
Lif & -57.621 & 0.0230 & 23.032 \\
\hline
\end{tabular}

Computed from field survey, 2010

$* *$ Significant at $5 \%$ level, $* * *$ significant at $1 \%, \mathrm{Ns}=$ Not significant

\section{Conclusion}

The findings showed thatlarger proportion(61.3\%) of malefarmerswere into cassava production in the study area. The mean age of cassava farmers was 42 years. This implies that most of the cassava farmers in the study area are active and have the capacity to produce efficiently. The result also showed that married couples $(50 \%)$ constitute the bulk of cassava farmers. The findings also showed that majority $(83.3 \%)$ of the sampled farmers were literate. The mean farming experience of the cassava farmers in the study area was 9 years. This implies that most of cassava farmers have been in cassava production for a long time. The result from this study showed that the major factors affecting cassava productions in the study area were farm size, family labour, hired labour, fertilizer, house hold size, years of schooling and source of funds. These factors were significant and have positive influence on cassava output.

\section{Recommendation}

Based on the findings of this study, it is recommended that:

(i) Agencies of government and other NGOs and International organizations concerned with agricultural development should make efforts to improve on the supply and availability of agro-chemical, cassava stem and fertilizer to enhance greater usage by the small scale farmers.

(ii) Access to credit by farmers must be guaranteed by the State Government through special programs to enable farmers acquire more productive modern inputs as well as other cost - elements in the production process.

(iii) Extension services, especially of the ADP should try to enlighten farmers to ensure better and more appropriate application of the modern inputs, especially the chemicals.

\section{References}

[1]. Aigner, D.J.; Lovell, C.A.K.and Schmidt, p.(1977). "Formulation and Estimation of Stochastic Frontier Production Function", Journal of Econometrics, vol.6, 21-37.

[2]. Battese, G.E. and Coelli, T. (1995). A Model for Technical Inefficiency effects in Stochastic frontier production function for panel data, Empirical Economics Vol.38, 387-399.

[3]. Battese, G.E.; Amilik,S.J. and Gill, M.A. (1996): An investigation of Technical inefficiency of production of wheat farmers in four Districts of Pakistan. Journal of Agricultural Economics, vol.47, No.1,37-49.

[4]. Battese, G.E. and Cora, G.S. (1977): Estimation of a prediction frontier model: With Application to the pastoral zone of Eastern Australia, Journal of Agricultural Economics, 21: 169-179.

[5]. Battese, G.E., Amilik,S.J. and Broca, S. (1993): "Production Function for Wheat farmers in selected District of Pakistant. An application of a stochastic frontier production function with time varging Inefficiency effects" The Pakistan Development Review, 32:233-268

[6]. Bravo-ureta, B.E. Boris E. and Antonio Pinheiro E. (1997): "Technical Economic and Allocative Efficiency in Peasant Farming: Evidence from the Dominican Republic." The Developing Economics, 35 (1): 48-67

[7]. C.B.N. (2011). Central Bank of Nigeria Annual Report and Statement of Account For the year ended, $31^{\text {st }}$ December, A publication of the Central Bank of Nigeria, pp.43-47.

[8]. Eno, H. (2004). Seven Billion Naira to be Tapped Wealth of Opportunities in the Cassava Processing Industry. Success Digest, October, 2004, Lagos pp 14-16 And 46-49.

[9]. Farrell, M.J. (1957). The Measurement of productivity Efficiency, Journal of Royal Statistics, Society Series A (General) 120 : 253-281.

[10]. FAO.(2003). Online Statistical Database. Rome, Italy: Food and Agriculture Organization of the United Nations, Retrieved on 27th June 2010 from www.fao.org.

[11]. Kopp, R.J. and Smith, V.K. (1980):Frontier Production Function Estimations for Steam Electric Generation : A Comparative Analysis .' Southern EconometricsJournal, 47(10): 49-59

[12]. Meeusen, W. and Van Den Broeck, J. (1977). Efficiency Estimation from Cobb-Douglas production functions with composed error. International Economics Review, 18(2) 435-444.

[13]. Ogundari, K.; Ojo, S, O. and Ajibefun, I.A. (2007). Economics of Scale and Cost Efficiency in Small Scale maize production Empirical Evaluation from Nigeria, Journal of social Science,13, (2) 131-136.

[14]. Ogundari, K.; Ojo, S,O. and Ajibefun, I.A. (2006). An Examination of Technical, Economic and Allocative Efficiency of Small Farms: The Case Study of Cassava Farmers in Osun State of Nigeria, Journal Central European Agriculture Vol. 7 (3), 423-432.

[15]. Ogunniyi L.T., Ajao, A.O., Olapade-Ogunwole F. and Ganiyu MO (2012). Resource-use Efficiency of Cassava Production in Atakunmosa Local Government Area of Osun State. Prime Journal of Social Science 1(2): 27-30. 
[16]. Ojo, S.O. (2004). "ImprovingLabour Productivity Technical Efficiency in Food crops: A Panacea for Poverty Reduction in Nigeria"' Food Agriculture and Enviroment, 2(2): 227-231

[17]. Comparative Analysis of oil palm farms in Ondo State, Journal of Agricultural, Forestry and Fisheries, 1: 40-46.

[18]. Onu, J.I. and Edon, A. (2009): Comparative Economic Analysis of Improved and Local Cassava Varieties in Selected Local Government Areas of Taraba State, Nigeria. Journal of social science, 19 (3) 213-217.

[19]. Ortega ,L, Ward, R and Andrew, C ( 2005). Measuring Technical Efficiency in Venezuela: The Dual-Purpose Cattle System (DPCS) in University of Florida IFAS Extension, 10(5), 22-27

[20]. TADP (2004): Crop Production Recommendation for Taraba State, Government Printer, Jalingo, Nigeria, pp.31-40.

[21]. Tanko,L. and Jirgi, A.J. (2008). Economic Efficiency Among Small holder Arable Crop Farmers in Kebbi State, Nigeria Continental Journal of Agricultural Economics, 2: 14-22

[22]. World Bank (2006): Millennium Development Goals. The World Bank Groups, Washington D.C, PP. 80 -86. 